\title{
Bolaño: Otra vuelta de tuerca de Patricia Poblete Alday
}

Santiago de Chile: Universidad Academia de Humanismo Cristiano, 2010, 148 pp.

Alejandra Oyarce Orrego Universidad de Concepción, Concepción, Chile alejandraoyarce@udec.cl

Datricia Poblete Alday, periodista de la Universidad de Chile, doctora en 1 Literatura Hispanoamericana y docente de la UAHC, acaba de sorprendernos con Bolaño: otra vuelta de tuerca (2010). El libro, de la Colección Ensayo de la Universidad Academia de Humanismo Cristiano, es resultado de la investigación posdoctoral realizada por la autora en la Universidad Complutense de Madrid, con el patrocinio de la línea de apoyo al perfeccionamiento del Fondo del Libro del Consejo Nacional de la Cultura y las Artes (CNCA).

Bolaño: otra vuelta de tuerca se organiza en tres capítulos. El primero, "Figuraciones", contiene tres subcapítulos: Ideaciones apocalípticas, 2666 $=i d o s$ mil seiscientos sesenta y seis?, Génesis. El segundo, "Imaginarios", se subdivide en: Topografía del mal, La estética de la Noche americana, verticalidad, Escatologia, El cuerpo y sus despojos, La figura del gigante. El tercero, "Perversiones", se organiza en tres subcapítulos: Duplicación y serialización, Enumeración y listas, Sentido del sinsentido. Además, destacamos que, en las páginas finales, se incluye una completa y actualizada bibliografía que informa de toda la obra del autor y los principales estudios críticos sobre la escritura de Bolaño.

Bolaño: Otra vuelta de tuerca aporta una lectura crítica actualizada de su narrativa, incluida la más reciente publicación de Anagrama, El tercer Reich (2010), y reafirma la posibilidad de realizar nuevas lecturas de la obra de Roberto Bolaño; como señala la autora, "en aquellas nuevas lecturas, ir ajustando un poco más esa tuerca -esa otra figura del espiral- con la que tratamos de explicarnos, más que el universo narrado, nuestra propia fascinación" (141). Esta afirmación resulta prácticamente indiscutible, si pensamos en la creciente masa de lectores y críticos interesados en la producción literaria de Bolaño que, bajo esa suerte de fascinación por la obra del escritor, posibi- 
litan un fenómeno editorial no conocido por otro narrador chileno y cuyo creciente interés puede constatarse también en la proliferación de artículos, ponencias y trabajos, en la mayoría de los congresos y seminarios literarios, posteriores a su muerte.

En este contexto, el trabajo de Patricia Poblete Alday es valioso y necesario para ir construyendo y consolidando un cuerpo de textos teórico-críticos dedicados al autor de Detectives salvajes, especialmente, desde el ámbito crítico-académico chileno.

El estudio crítico se centra en una obra en particular, 2666 (2004); acaso una de las más llamativas y sugerentes. Entendida ésta como obra terminal, la lectura de Patricia Poblete Alday propone un paralelo entre esta novela y el apocalipsis, el que puede rastrearse en varios sentidos, considerando que 2666 se inscribe en la tradición apocalíptica, aspecto confirmado por el propio autor en el texto de Entre paréntesis (2004) "Sergio González Rodríguez bajo el huracán”. En este artículo, Bolaño se refiere a la tradición apocalíptica como una de las dos tradiciones vivas en Latinoamérica y que, en términos narrativos, ofrece la posibilidad de acercamiento al abismo que rodea a nuestro continente. Este paralelo entre 2006 y el apocalipsis es también abordado por Edmundo Paz Soldán en "Roberto Bolaño: Literatura y apocalipsis", artículo que forma parte de Bolaño salvaje (2008). En él, Paz Soldán propone una lectura que hace dialogar los conceptos de literatura y apocalipsis, centrándose en "Apocalipsis en Solentiname" de Julio Cortázar y el apocalipsis en la obra de Bolaño, incluyendo 2666, principalmente desde las dimensiones de violencia y horror. A través de su lectura llega a establecer que el imaginario apocalíptico es el único que le hace justicia a Latinoamérica, sobre todo de los años 70 y así se verifica en la obra de Roberto Bolaño, especialmente en textos como Nocturno de Chile (2000) y Estrella distante (1996), luego coincidimos también con la apreciación del autor, que a partir de 2666 esta imagen del apocalipsis se extiende en términos planetarios.

El apocalipsis, según Patricia Poblete, puede ser entendido como el eje rector para el análisis de 2666 y a partir de esta idea se examinan determinadas dimensiones de la novela. En primer lugar, aparece el carácter terminal de la escritura, ya que se trata de la obra que Bolaño está escribiendo en el momento de su muerte. En segundo lugar, surgen los espacios que se presentan en la obra, los que son terminales, tomando sobre todo como lugar central el valle de la muerte que es Santa Teresa; la topografía del mal que se abre en la novela es totalmente abordable bajo la idea de una seguidilla de espacios apocalípticos, así como también lo es el tiempo, dimensiones que se han diluido y que sólo resultan perceptibles como intensidad. En tercer 
lugar, la novela nos enfrenta con el horror de la muerte, a través del masivo asesinato de mujeres de Ciudad Juárez, que da paso a la serie interminable de cadáveres encontrados; así como también, el horror de la muerte real del escritor. En cuarto lugar, nos encontramos con personajes, imágenes y tópicos terminales, como la recurrente presencia del abismo y la ceguera que, de manera literal o figurada, convergen en el imaginario apocalíptico de la novela y que, como bien lo advierte la autora, son utilizados en toda la obra precedente de Bolaño, por lo que constantemente debemos estar mirando hacia atrás para conectar éstas imágenes.

A través de detalladas descripciones, sugerentes conclusiones y arriesgados análisis que dan cuenta de la notable investigación que la autora ha desarrollado acerca de la obra de Bolaño, podemos coincidir que 2666, leída desde el registro apocalíptico, es no sólo un nombre o una fecha, sino que encierra un misterio; pero que, por sobre todo, es lenguaje en estado terminal, en la medida en que bajo este título se intenta condensar la imposibilidad de racionalizar la realidad, bajo el dominio del mal y del horror, por lo que coincidimos con una de las conclusiones de Patricia Poblete, pues "es la propia realidad la terrorífica, y que la literatura no ha hecho nada más (ni nada menos) que descubrirla" (103).

En el último capítulo, específicamente en "Sentido del sinsentido", encontramos insinuada una de las dimensiones cuyo desarrollo nos parece fundamental, pues su estudio en profundidad prolonga la reflexión propuesta por Patricia Poblete Alday. Se trata de otro elemento central en la novela, el carácter terminal de la crítica literaria. Este tema es rastreable también en toda la obra del escritor y, particularmente, en 2666 ocupa un lugar principal, al introducir los editores la obra con La parte de los críticos. La figura del crítico literario actual es presentada a través de cuatro personajes: Moroni, Pelletier, Espinoza y Liz Norton, quienes desde su actividad experimentan situaciones límites. Los cuatro dedicados sólo a sus carreras, expertos en Archimboldi, doctores y directores de sus respectivos departamentos, consagrados como los hiperespecialistas en la obra de Benno von Archimboldi. Sin embargo, en este contexto terminal y de una manera incomprensible, estos expertos en lenguaje y literatura protagonizan también escenas de violencia extrema, como el episodio en que inexplicablemente golpean de un modo brutal a un taxista paquistaní y lo dejan agónico en medio de la calle, luego de una discusión sin sentido producto de una cita involuntaria que les parece que el taxista hace de Borges al referirse a la idea de Londres como laberinto. No sin antes limpiar sus huellas dactilares, abandonan moribundo al taxista y, más tarde, al comentar el episodio "hablaron de la sensación que sintieron 
mientras golpeaban el cuerpo caído. Una mezcla de sueño y deseo sexual" (2004: 105).

Bolaño presenta a la crítica literaria actual como una actividad límite, que experimenta también un momento terminal. Roberto Bolaño muestra a los críticos, expertos en literatura y particularmente, en la obra de Archimboldi, desde una visión marcadamente crítica respecto del ejercicio de la crítica literaria, aquélla que a él mismo mantuvo ausente de la escena literaria y que, sobre todo desde su muerte, lo mantiene omnipresente. En la novela, los críticos conocen todas las publicaciones, las han releído, criticado e incluso algunos como Pelletier y Moroni la han traducido. Han llegado a ser los especialistas de mayor jerarquía en Archimboldi y desean ir aún más allá de la obra, quieren encontrar al escritor, lo que los impulsa a emprender una intensa búsqueda, así como los detectives salvajes parten tras Cesárea Tinajero, los archimboldianos parten tras el escritor. Desean encontrarlo, aunque sólo poseen datos vagos a cerca del paradero de Hans Reiter. Anteponen la voluntad, aquel rasgo predominante que comparten, por sobre cualquier razonamiento lógico, su objeto de estudio se transforma en objeto de deseo, pues, como lo advierte Patricia Poblete, muestran el intento extremo de unir literatura y vida. Sin embargo, en la intensidad que determina la búsqueda de Archimboldi se encuentran a sí mismos, con sus deseos personales, lejos de las conversaciones ultrasofisticadas que protagonizan al principio del capítulo en coloquios, seminarios y congresos. Norton acepta que lo que realmente desea es estar con Moroni, Espinoza se dedica a recorrer la ciudad y a conquistar a una joven vendedora de alfombras en Santa Teresa y Pelletier, convencido de que el logro de la búsqueda consiste en haber estado lo más cerca posible de Archimboldi, decide regresar a los libros que casi había olvidado, el crítico vuelve a ser lector y desea simplemente disfrutar de la lectura de la obra de Benno von Archimboldi.

Desde una situación claramente marginal respecto de los poderes institucionales representados por los intelectuales expertos, que se sitúan y perpetúan en la academia, ejerciendo su poder amparados en una idea del saber hegemónico y monolítico, Roberto Bolaño logra dar cuenta del estado terminal de la literatura y aun así logra encontrar una escritura en la que es posible desplegar su pensamiento crítico marcado por un agudo e irónico tratamiento de la crítica y del intelectual. Esto se percibe con claridad en uno de los momentos en que Amalfitano, el profesor chileno que también conoce la obra de Archimboldi, analiza a la figura del intelectual: "Emplean la retórica allí donde se intuye un huracán, tratan de ser elocuentes allí donde intuyen la furia desatada, procuran ceñirse a la disciplina de la métrica 
allí donde sólo queda un silencio, ensordecedor e inútil. Dicen pío pío, guau guau, miau miau, porque son incapaces de imaginar un animal de proporciones colosales o la ausencia de ese animal" (2004: 163). La incapacidad de imaginar y de crear, la vanidad de análisis cargados de retórica vacía y la falta de originalidad, son algunas de las duras críticas que Roberto Bolaño entrega en la novela, a través de personajes tan excéntricos como el profesor Amalfitano, y que están presentes en toda su obra.

El estado terminal de la crítica es un rasgo que reafirma la lectura propuesta por Patricia Poblete Alday, en la medida en que la crítica forma parte de la perversa realidad de la que da cuenta la obra literaria de Roberto Bolaño que logra captar las problemáticas contemporáneas, registrar el ocaso del intelectual moderno y el estado de descomposición del campo literario y de la crítica. Pero, al mismo tiempo, nos deja la posibilidad de imaginar un nuevo pensamiento crítico desde la literatura aun en estado terminal, lo que supone una nueva crítica y un nuevo tipo de intelectuales críticos. 